\title{
SELECTED $20^{\mathrm{TH}}$ AND $21^{\text {ST }}$ CENTURY REPRESENTATIONS OF TRIBALISM AND MODERNITY IN SOUTH AFRICAN LITERATURE: REASSESSING SOCIO-HISTORICAL PROCESS THROUGH (RE)CONSIDERATIONS OF WORKS OF VERBAL ART
}

\author{
Annie Gagiano \\ Stellenbosch University
}

\begin{abstract}
Opening with a brief historical contextualisation, the article takes the reader back to humanity's prehistoric origins in southern Africa, then to its (and mankind's) earliest known culture, that of the San/Bushmen, followed by the (returning) migrations of Khoikhoi and Bantu peoples to the area. Using seven literary texts, discussed in their order of composition, the article discusses these evocations as representing a spectrum of ways in which regional tribal cultures were, are or may be seen. The Khoikhoi elder Hendrik's tale, told as well as transcribed in Afrikaans [now available in an English translation], is the first text; it addresses the ability of a tribal culture to correct a leader's power abuse by means of verbal art and skill. Secondly, the great Xhosa poet S. E. K. Mqhayi's advocation of a balance between tribal and Christian values is addressed, followed by Bessie Head's critique of women's denigration, seen as facilitated
\end{abstract}


by Batswana tribal and modern cultures. Lauretta Ngcobo in her second novel evokes a dignified rural black woman's struggles with the exclusionary and oppressive effects of both apartheid and Zulu tribal customs, while Zakes Mda's novel achieves a wise and ironically tinged balance in depicting tribal traditionalism and modernity in a Xhosa village. David Donald's is a delicately empathetic evocation of a dwindling Bushman culture beset by both white and black incursions in early colonial times, while (lastly) the essay considers the recent novel by Thando Mgqolozana which warns, in a devastating account, of the physical and psychological harm effected by the deteriorating practice of circumcision of young males among the AmaXhosa. This mosaic of texts establishes the strengths as well as the dangers of a range of southern African tribal cultures over a range of time and in different settings.

Keywords: tribal/ism, modernity, apartheid, custom, uneasy oscillations.

In order to address the evolution of tribal cultures in South Africa, and to come to the main focus of this article-which is on specific, presently available published texts that concern themselves with, or embody, significant encounters between tribalism and modernity in southern Africa-one needs to go far back in history to a period where what is known is and will remain a little hazy. South Africa has staked a claim to having "The Cradle of Mankind" (the name assigned to a particularly significant archaeological site in Gauteng province, just northwest of Johannesburg [around Sterkfontein or "strong fountain"]), but there are competitors in Kenya and further north in Africa and elsewhere. In the long time-frame, the South African dating goes back to about 2.5 million years ago for the local emergence of human life. It appears to be fairly widely accepted that a child's skull found in 1925 in South Africa at Taung near Kimberley in the Northern Cape Province was validly classified as Austrolopithecus africanus, marking the evolutionary transition 
from apes to humans. In 1947 an adult skeleton of Austrolopithecus africanus was discovered onsite at Sterkfontein and nicknamed "Mrs Ples" (Wilson 20-21). Africa, and probably southern Africa, is hence a possible site of the emergence of humankind and the location from which human beings spread out across the entire earth, diversifying during the course of these age-long journeys.

The San or Bushmen people-the earliest known human communities-lived for many thousands of years in southern Africa. Of the numerous click languages ${ }^{1}$ spoken by them (not, apparently, mutually intelligible), some few were recorded, and small groups of speakers remain. Their lifestyles could perhaps not be described (strictly speaking) as tribal, since the San lived in small roaming family groups of usually between twelve and twenty people; surviving by hunting among the teeming hordes of game that filled the region, and by gathering edible plants, seeds and roots as well as seafood along the coast-males doing the hunting and women the gathering work of these groups. The very name to call these earliest of humans and South Africans is perennially in dispute: the Bushmen/San groups [I use the terms interchangeably] had no overarching term for themselves as they were not a united people. The name San is a word in the language of the Khoekhoe, ${ }^{2}$ and it is at best condescending and at worst derogatory, meaning (and hence indicating the 'superior' perspective assumed by the Khoikhoi pastoralists) something like "people without cattle" or "vagrants". The alternative name for them is Bushmen, translated from a Dutch colonialist term and seemingly even more insulting-yet (be it noted) many San descendants prefer this name.

Theirs was a culture whose complexities are insufficiently understood, but that they had a culture exceeding the practicalities of survival in its sense of beauty and grace and that they practised 
communal healing rituals, played musical instruments and recorded spiritual experiences cannot be denied. Thousands of San rock art sites, the oldest of which is about 26,000 years old, are found throughout southern Africa. According to Wessels, the richest verbal source for the lore of the Bushmen is that of a Northern Cape San group-the recorded interviews that a German philologist Wilhelm Bleek and his sister-in-law Lucy Lloyd made of the cultural testimonies of a small /Xam family group whom they employed in Cape Town during the 1870s, learning and devising an orthography for the /Xam language and providing and recording parallel English translations of their transcriptions. Some few haunting expressions out of the many hundreds of pages recorded by Bleek and Lloyd have become famous, such as the remark of the elder /Kabbo (whose name means Dreamer) that "a story is like the wind, it comes from a far-off quarter, and we feel it". ${ }^{3}$ Appropriately, the new national motto of democratic South Africa is in the /Xam language.

If the southern African "cradle of mankind" claim is valid, there must have been a gradual northern exodus further into Africa (and beyond), probably quite slow and intermittent, and then, in staggered influxes, stronger tribal presences began to assert themselves, returning from central, eastern and western to southern Africa, while others proceeded further north- and east-wards into other continents. The first of these 'returning' pastoralist incursions was by the Khoikhoi, often classified with the San in the inclusive term Khoi/ San-because there were clear physical and linguistic resemblances between the San bands and the Khoikhoi. Seemingly the Khoikhoi spoke one language-they may have been a particular San group who had grown taller and become dominant because of their more regular and protein rich diet, since they had acquired livestock (herds of cattle and sheep) in the area that is now northern Botswana. They 
erected their portable dome shaped huts at their grazing and watering source encampments instead of just using rock shelters like the San/ Bushmen, and had a different religion and a human (Khoikhoi) hero figure in their lore, one believed to reincarnate himself periodically. But some mingling and intermarriage did occur among Khoikhoi and San, as well as surmisable clashes over water sources in the more arid regions and periods, and sometimes poaching of beasts by the Bushmen. Property is theft, it has been said; property is also that which may be stolen: perhaps the long history of inter-tribal clashes in South Africa began here (Smith et al. 47-55).

Bantu-speaking people whose appearance (generally taller and mostly fuller-fleshed) had changed more markedly from that of their San ancestors' than the Khoikhoi had; who practised diverse crop cultivation, had greater expertise in metal-working and in pottery and were of darker pigmentation, began to advance southwards from about 1,500 years ago-possibly from west-central Africa and the great lakes region. Theirs were more hierarchical tribal societies who developed settlements where some stayed on, such as the first identifiable southern African town of Mapungubwe, originating between 600 and a thousand years ago. The following Bantu tribes arrived consecutively: the Venda/Shona earliest, keeping to the north of the southern African region, then the Nguni (which includes the Xhosa, Swazi and Zulu peoples) along the south-east of this region, and later on the Sotho/Tswana, who settled in the northern central parts of southern Africa-a process beginning roughly from the first half of the $1^{\text {st }}$ century A.D. and continuing until the 1600s. The amaXhosa, who came down furthest into and along the southeastern parts of South Africa, had the most extensive contact with the Khoi/San groups; intermarriage occurred and the Xhosa language absorbed its three "click" sounds from these predecessors. 
The earliest European settlement began during the 1650s at the southern extremity of what is now Cape Town, initially explicitly as a mere supply station for Asia-bound Dutch ships, but soon (inevitably?) the settlement began to expand and became a colony. Clashes over grazing areas intensified between the Khoikhoi and the first Dutch settlers, whereas the Bushmen were increasingly being driven out and killed off by both European and Bantu farmers, or were deprived of their traditional food sources. We know that there was some more amicable intermingling, too, with San rainmakers (for example) being employed by the Bantu farmers, while the facial features and lighter skin colouring of Xhosa people indicate intermarriage with San and Khoikhoi. Yet inter-tribal clashes were often fiercely violent and bloody; the establishment and extension of the Zulu kingdom in particular had a domino effect; this period was terrifyingly known as the difeqane, meaning "the crushing". One outstanding example of humane conduct during this terrible time was the pronouncement by the Sotho King Mosheshwe who, when his people brought him the man who had captured, killed and eaten the king's own grandfather, said humorously that he would not disturb the grave of his grandparent; he also pronounced (more solemnly): "Men cannot eat stones. Let it all be forgotten." extensive enslavement of local tribal people in South Africa; in the mid-1700s, slaves were brought from north-east Africa and the Dutch Asian colonies (including parts of India) to work for the European colonists, and numbers of Indian indentured labourers came in the 1800s-early 1900s, arduously employed and harshly exploited by the white, European descended, predominantly English-speaking cane sugar farmers in the region of present day KwaZulu-Natal.

The second major European influx was by British settlers in and following 1820; many bitter border wars and power contestations 
were fought between and among the Xhosas, Zulus, DutchAfrikaners and British and other groups. Some ascribe the virulence of the apartheid system to the humiliation of the Afrikaners by the British in and following the Anglo-Boer War of the early 1900s; the fierce cohesion and fanatic land-love of white Afrikaners on which apartheid depended caused them to be labelled the white tribe of Africa. Apartheid rulers employed divide et impera (divide and rule) techniques to diminish what to them was the threat of black South African intertribal cohesion; the cruel oppression, civic exclusion of and cultural denigration practised towards the indigenous peoples of South Africa was a scandal to heaven.

Yet, neither apartheid nor earlier forms of Dutch and later British racial contempt succeeded in exterminating the tribal cultures of South Africa. The colonial and later apartheid economy required only a barely literate, predominantly male and urbanised black participation. Black land ownership was ruthlessly reduced to $13 \%$ of the land surface of South Africa-an area incapable of sustaining the black population. Rigid influx control was practised, but of course large numbers of (poorly paid) black employees were required to work the mines, other industries and on the whiteowned farms. The destructive intervention of these changes in black tribal and family life can be imagined. But if apartheid black urbanisation detribalised many blacks, the vast majority were yet not incorporated above the most minimal level into Western modernity. Verwoerd's notorious justification of the low and poor level of education available to blacks during the apartheid era is well known. If apartheid was one and a particularly brutal form of modernisation, it was also an exceptionally cunning system in simultaneously reducing the strength and resources of tribal cohesion, yet putting so restrictive a ceiling on the development into 
full modernity of black South Africans. I make the above points to indicate why the acquisition of dedicated educational institutions and political non-tribal organisation mattered so much, as vital strategies of resistance and advancement, to black South Africanseven if they in certain respects involved, or required, both changes to and losses or deliberate sacrifices of particular tribal practices.

Four of the dates on the addendum headed "Key Events in South African History", in a useful book, ${ }^{5}$ mark the establishment of important modernising institutions for black South Africans-in 1841, Schrire's note tells us, the "Lovedale Missionary Institution [was] established in [the] Eastern Cape, [as the] first African secondary school"; in 1884 the "First African-edited newspaper started"; in 1912 the South African Native Congress (the SANC, forerunner of the ANC) was founded as the first inclusive black South African political movement, and in 1916 the South African Native College open[ed] at Fort Hare, Eastern Cape: this was the first dedicated tertiary educational institution for black students in South Africa.

The literary examples to which this article refers cover much of the same ground, but the last few of them also take us beyond the legal ending of apartheid to encounter certain contemporary challenges to as well as some of the enduring, living forms of South African tribal culture in its engagements with modernisation processes. These examples are carefully selected to give something of a geographical, historical and cultural spread; they are introduced sequentially in their order of publication, but some of the echoes and linkages among these seven texts-both intertribal and intratribal-will be indicated. Each text is briefly placed chronotopically, to employ Bakhtin's terminology. The first marker of modernity vis-à-vis the Dwaalstories [an Afrikaans word meaning both or either wandering/ meandering or wanderers' stories], the first text addressed, is of course that we 
have them written down and available in book form; the four brief tales are an example of recorded, but previously intratribal, orally transmitted narratives. The title of the recently published English version ${ }^{7}$ is misleading; only the briefest story, about a "Rain Bull"-a mythological creature with no relation to cattle-features an aspect of the belief system of the Bushmen. This story is likely to be the most ancient of the four. Interestingly, its contents contradict romanticised images of San life as taking place in an harmonious society free of social tension; self-correcting and perfectly balanced; in this story there are examples of malice; evil witchcraft practices resulting in an old woman being suspected of murdering her own daughter; expulsion or exile of some members of a clan and sibling rivalry. It is also a story of innocence (inner and outer beauty) rescued to dwell in a magical underwater world.

The three other stories all contain references to the Khoikhoi culture. The fact that all the stories were recorded neither in the Khoikhoi nor a Bushman language but in the Afrikaans tongue, which was the lingua franca between the elderly narrator Hendrik (of whom we know only this Dutch colonial name) and the scribe, a noted Afrikaans author of this time, is clearly another modernist factor. The background of this story in the intrusive form of modernisation that we call colonialism is readable from this fact since, at this time, Afrikaans had just recently 'emerged' from seventeenth century Dutch, the colonial language adapted to indigenous as well as Asian slaves' languages, and at the time South Africa was still a British colony, while it is by means of the non-tribal outsider Marais's transcription and his access to the publication process, that these four profound and precious stories have been preserved. Nevertheless, further harm to tribal cultural wealth came about in the process. Even though Eugène Marais, the white Afrikaans transcriber of the Dwaalstories, both 
scrupulously and explicitly acknowledged Hendrik as their narrator in his Introduction to this small collection, the Afrikaans literary establishment in South Africa appropriated the stories by attributing their authorship, beyond the deaths of both Eugène Marais and Hendrik, exclusively to the white Afrikaans author.

I would like to convey some impression of the vividness, resonance and verbal beauty of the most complex of the Dwaalstories, the one titled (like the poem in the addendum) " "The Song of the Rain"the poem through which the story culminates. It needs to be borne in mind that certain historical and cultural references in the story indicate that it originated in the arid Northern Cape region of South Africa, where drought at times became a life-threatening problem to the Khoikhoi-as it does in this story, which could incidentally have been composed, or more likely was adapted to its present form, in the mid nineenth century. Marais heard the stories from Hendrik in a lush, mountainous region in South Africa's most northern province, Limpopo; so the stories had indeed wandered by the time he heard them, while the elderly Hendrik appears as a solitary nomadic figure, rather than one living within a tribe.

"The Song of the Rain" is a tale that brilliantly evokes community, character, culture and setting, yet the story can be read as a significant political parable, relevant and educational to other times and settings. It is a story of a survival and leadership struggle during a period of crisis brought on by drought, featuring an appointed guardian who betrays trust and becomes a selfishly possessive usurper as well as a hypocritical old pretender who falsely claims to be able to save his people from the usurper yet also depicting the true, but humble, saviour-figure to whom leadership is eventually transferred. The story also features a figure of authority who is a female elder; she is the repository of ancient tribal lore and community ethics, whereas the saviour-figure is an artist and an inventor. 
As a social study, this tale does not portray tribal society as either static or free of conflict and stress, or of abuse and deception. It valorises quiet perseverance and courage as much as it celebrates the power of art and a humane feeling for justice. The central place and site of significance in the tale is a water source which is the community's emergency water supply for times when the depredations of drought become unendurable. But the man whose task it is to guard this source from depletion, so that it will be there for the community in times of crisis, has grown so arrogant that he fences it in as his personal possession and allows no access to it. The clan holds a meeting where a man of previously high standing but outdated skill coyly claims that he will regain access to the water for his people, but he is an old fraud and does not even attempt the task, while a younger, seemingly insignificant member of the group, burdened with a hunchback, creates a new kind of musical instrument and composes and performs the lovely "Song of the Rain". In thus proving himself a creator and inventor, he inspires everyone to back him and, by means of his artistic and unassertive organisational skill, peacefully wrests the leadership from the mere power-violence of the usurper-who is humiliated and unseated. The poem ending the tale (see the addendum) conveys a feeling of wonder and celebrates the return of the rain and the regaining of the water sources.

The next text featured here was very recently published in South Africa; the book is a collection of historical and valedictory essays retrieved from old newspapers by a leading British scholar, Jeff Opland, written by the greatest of the Xhosa writers: the poet S.E.K. (or Samuel Edward Krune) Mqhayi. On Mqhayi's memorial tombstone was written, in isiXhosa: "Poet of the Nation, author of books, / Royal councillor of all the Xhosa people, / Leader, true Christian". The cited words are merely an extract from the inscription 
on Mqhayi's grave (Mqhayi 1), but they convey the perhaps paradoxically successful way in which this author was able to act as a custodian of his people's culture; a reminder and recorder of tribal history; himself a creator of Xhosa culture whose prolific writing in both poetry and prose was always only in his mother tongue, yet simultaneously a man who always insisted that some amaXhosa traditions had to be abandoned while Christian doctrine should be fully accepted and the technologies of the literate modern world should be acquired. ${ }^{9}$ While Fanon's distinction between "custom" as rigid and "culture" as an ongoing adaptive process may be useful here, ${ }^{10}$ it helps to know that several important aspects of African and here particularly Xhosa culture, resembled Christian teaching and facilitated its quite speedy assimilation. For example, the amaXhosa have a 'resurrectionist' belief system: not as in reincarnation, but in their conviction that human beings after death live on as "Ancestors" who are profoundly revered. Hence Mqhayi can with great pride proclaim (in one of the many elegies for departed Xhosa figures of public importance of which this collection consists): "We Xhosa do not die; /...We're people whose bull's blood speaks;/ we're people of spirits and ancestors -" (218).

Other factors in Xhosa culture that allowed it quite easily to absorb Christianity include the belief in the value of humaneness and public spiritedness. Mqhayi's most famous poem, which is not part of the collection of largely prose writing I have cited, evokes a World War I event when most of about 900 black South African enlisted men drowned as their ship was sunk in the English Channel. Mqhayi writes of the dead men (as translated into English): "You didn't die ... to kowtow to Britain", but says that they "were opening the road to freedom" for their people, and he ends: "How I wish I could sparkle with them like the morning star". ${ }^{11}$ Alas, the hope that Britain would 
reward black South African loyalty by granting them citizenship in their own country, South Africa, would be betrayed.

In 1938, while still at school, Nelson Mandela witnessed one of Mqhayis poetic performances, and Mandela wrote of this performance nearly 60 years later in his Long Walk to Freedom: "I felt such intense pride at the point, not as an African, but as Xhosa" (Mandela 49). ${ }^{12}$ Though intensely pro-education, in fact a campaigner and tireless advocate of black South African advancement through acquisition of literacy and technological skills, Mqhayi was fiercely scornful of the way the mission schools taught "the history of only one nation", the British, and he often denounced these schools' Eurocentric claims that Xhosa chiefs defending their people's rights were "sly"; that the great men of this nation were "thieves [and] cowards" (28). It is in order to counter this education of his people in cultural humiliation, one may surmise, that he so tirelessly teaches about great Xhosa men and women of the past and present in the pieces in this collection, and that he utilises the modern medium of the Xhosa-language newspaper to teach his people about their history and about contemporary amaXhosa public figures.

The amaXhosa (that is, the Xhosa people) practise male circumcision as an initiation rite-something that is the main topic of the last of my chosen texts. Even though the missionaries at the high school he attended had forbidden it, Mqhayi left for his home to undergo the circumcision ritual as a gesture of fidelity to his tribal culture, returning to school afterwards. Throughout this collection of essays, written over the course of forty years, Mqhayi advocates a judicious balancing between the traditional and the modern. He writes with respect (for instance) of the way an earlier Xhosa king had managed the contradictory demands of two prophets: one a Christian visionary advocating accommodation of 
the British colonialists, and the other a hothead demanding military confrontation. Mqhayi reports admiringly how in the early colonial days, another Xhosa king had resolved a case of insubordination by a slave that was brought before his court, by declaring (to the white slave-owner): "Here in Xhosaland there is no such thing as a slave", and releasing the latter from bondage. When the furious slave-owner protested at this judgement, Maqoma (the Xhosa ruler) told him (as Mqhayi reports): "You boast that your people are wiser than ours,-the fact that you dispensed with discussion and resorted to the stick suggests otherwise,-physical power has nothing to do with mental power"' (130). But Mqhayi does not deny, indeed, he is proud that the amaXhosa were a warlike people, engaging in an almost interminable series of wars and battles with colonising forces in defence of their land, before they were finally quashed.

The major event that, perhaps more than military subjugation, brought the amaXhosa to their knees-viz. the great Xhosa cattlekilling of 1856-57-also features largely in the novel The Heart of Redness, to be later discussed. The cattle-killing of the mid-1850swhen a majority of the amaXhosa destroyed their cattle in response to the prophecy of a young Xhosa girl, Nongqawuse, who prophesied that to do so would cleanse the nation; that new cattle would come out of the sea and that the Ancestors would be reincarnated to save the Xhosa tribes from the colonial incursion, driving the colonists into the ocean-is in one of his pieces interpreted by Mqhayi as a disguised blessing that flung his people into modernity and aided them in eventually finding a dignified place for themselves in a changed world political system $(74 ; 78 ; 80 ; 384)$-despite the devastation it caused at the time. Discussion of Mqhayi's balancing of tradition and modernity for his people can be brought to a close by a citation from Mqhayis isibongo (which means 'praise poem') in honour of an early ANC 
leader, Dr. A.B. Xuma: “The one with veins like wire;/ to lift a Xhosa and Zulu -/ a Sotho and Tswana will swing" (528). Here Mqhayi refers to the point that black South Africans' intertribal rivalries had to be overcome to force a strong political movement that would eventually defeat colonial and apartheid racist exclusion.

Bessie Head's brilliant group of short stories-published in the late seventies as The Collector of Treasures and other Botswana Village Tales (1977)-features in the argument of this article for two main reasons: firstly, because they exhibit another southern African tribal culture, albeit as observed and analysed by an outsider who became insider, the bi-racial but black-classified, exiled South African author Bessie Head-who wrote almost exclusively about Botswana and 'adopted' the country as her own in "a gesture of belonging" (A Question 206)-and secondly because, like Mqhayi, Head deeply appreciates the tribal culture while identifying some of its less desirable aspects. In particular, in this collection, she focuses on the lot of women in a modern society continuing to function in ancient ways, which under such radically changed circumstances profoundly disadvantages the female population. Hence, Head analyses the deterioration of custom and shows how the ancient tribal gender hierarchy has persisted into modern times, whilst it no longer offers women the social security it used to.

She writes trenchantly but also dispassionately as an open-eyed, judicious observer free of vulgar anti-male stridency as she considers "three time-spans" of Botswana social life. Head describes one kind of man, on whom she blames the "breakdown of family life" (and indeed, mother-headed households were and still are common in Botswana). In former times, she writes, this kind of man "lived by the traditions and taboos outlined for all the people by the forefathers of the tribe" (91). The traditional laws, Head finds, functioned as 
"vast, external disciplines for the good of the society as a whole"; yet one of the forefathers' most serious "errors", she declares, was very "bitter-making" in that it "relegated to men a [permanent] superior position in the tribe, while women were regarded, in a congenital sense, as being an inferior form of human life." Then the colonial era came along and "broke the hold of the ancestors", and with it the old, traditional form of family life", separating men from their families to earn money in the modern economy (Head 91-92).

The third stage Head evokes came about (as she writes) when "independence suddenly and dramatically changed the pattern of colonial subservience" and many men "spun away [...] in a dizzy kind of death dance of wild destruction and dissipation" (92). Is Head seeing dissolute men whereas Mqhayi in his society focuses on dignified leaders because she is an outsider embittered by her own single-parent life, whereas the Xhosa poet writes from the centre of his society? Or is Head's merely a later time, when what Marxists call a comprador class has arisen? Two points must be noted: firstly, a number of other southern African women writers such as Unity Dow in Botswana and Gcina Mhlophe and Sindiwe Magona in South Africa have raised voices in similar protest in their texts; secondly, Head makes no blanket condemnation of males, but beautifully delineates also the very opposite, admirable kind of man whom she sees as part of this society: one who "has turned all his resources, both emotional and material, towards his family life" (93). Head's is a nuanced depiction of the interplay of tribal traditionalism and modernity, especially as it impacts on family life and gender relations; she is a deeply thoughtful, socially perceptive writer.

Partly because it is its chronological successor, but also because this writer, too, who is a tribal 'insider', addresses and balances both hurtful and healing aspects of tribal life from a female existential 
perspective, I move from Head's village tales to Lauretta Ngcobo's And They Didn't Die, published 1990. As the title announces, the novel's narrative is a tale of survival, but Ngcobo's visceral writing is heart-wrenching rather than triumphalist.

Ngcobo herself had a Zulu father and a Xhosa mother and her text is set in a rural area at the edge of KwaZulu-Natal and in a largely Xhosa-speaking region. It is a celebrated text; often referred to as the only major novel in English detailing the lives of rural black South African women, and it is set during the apartheid era. Its focal character is a very vital and generous-hearted young black woman who lives (initially, entirely contentedly) in her hillside tribal community; the main and troubling incursion into her life at first being the fact that her young husband has to work as a migrant labourer under the pass law system, far away in Durban, allowing the two of them to live together as man and wife for only two weeks of the year-during her husband's annual leave. Soon, however, harsher problems begin to beset her. One of the core sentences in the text reads: "She felt trapped between the impositions of customary law, state law and migratory practices" (40).

Like Bessie Head, Ngcobo convincingly details how certain Southern African tribal practices hamper women's self-fulfilment while the writer also registers some of the resources a tribal community offers. The main difference between the two somewhat modernised tribal societies that these authors depict is that in Ngcobo's And They Didn't Die, cultural oppression occurs alongside apartheid political oppression while also binding the oppressed together in protective solidarity. The author suggests that, given the fact of apartheid's intervention, the tight customary familial rules and roles of the tribe should have offered some leeway and been compassionately relaxed; the novel depicts the family-shattering results of the terrible co- 
incidence of Afrikaner dominated apartheid and customary laws for women like the protagonist at this time: an accidental, destructive 'conspiracy' of oppressive forces, as Jezile experiences it.

The "waiting" life of the migrant labourer's wife is what impinges first on Jezile, but then she has to endure her motherin-law's "relentless", insensitive badgering about when she will fall pregnant. She knows that the older woman's harshness towards her is the inheritance of a life that for her mother-in-law, too, had wasted away in waiting and that her mother-in-law had, like her own mother, "lost [her husband] in the waiting" (11). ${ }^{13}$ When Jezile becomes preemptive and breaks the rural women's political pact by applying for the hated "pass" (a permit) so that she can legally visit her husband in Durban, she has to endure both the accusations of betrayal from her female political allies, as well as her mother-inlaw's anger and suspicion-for Jezile had not asked her permission before making the visit, knowing she would be unlikely to grant it. At least Jezile has fallen pregnant during the visit, but motherhood is far from an unmitigated joy since, as Jezile discovers, local tribal custom places young mothers "in a permanent state of dependency and estrangement" (55), kept under constant watch for the least sign of infidelity or independence, and apartheid's harsh and cruel land deprivation makes mere survival a terrible, dangerous struggle for an impoverished people. Then her husband is jailed for stealing milk from an English farmer to save their little daughter from starvation.

Ngcobo does show instances of tribal coherence in the community as a whole and in the women's religious-cum-political association. Nevertheless the very opposite of the compassion and solidarity one might have expected is shown towards Jezile by her husband's family when she returns pregnant from the far off Free State province-where she had been obliged to go and work for an Afrikaner family to ensure 
her two little daughters' survival. Her white employer had raped her, but the resulting birth is blamed on Jezile and seen chiefly as presenting a problem of familial assignment-and as a scandal in the Church. In the end, Jezile has to leave her jailed husband's place to go and live with her own mother. When-some few years later-her husband is set free from jail, Jezile's daughters are in a terrible moment taken away from her to live with their father, to whose family the rules of tribal custom decree that they belong. In the horror of this moment Jezile utters a heartfelt scream of agony against such "unyielding, primeval ... primordial [tribal] laws" (226).

Much later, when both her second daughter and her illegitimate son have become anti-apartheid activists, Jezile's eldest daughter is about to be raped one night by a white Afrikaner soldier. Desperate to protect her child, Jezile stabs him to death, but before she presents herself for arrest and whatever harsh judgement (quite likely, a death sentence) awaits her, she goes to her estranged husband whom she has never seen since before he was jailed, to tell him what happened. Even as she reproaches him for never having given her an opportunity to explain the circumstances of her rape and her white son's birth to him, Jezile sees that her husband still loves and has an undying commitment to her-but now, when it is forever too late, after he had allowed tribal custom to decree their permanent separation, the realisation only adds to the tragedy and injustice of her fate.

The next and more recently published text, Zakes Mda's The Heart of Redness (2000), is a far more cheerful narrative in its perspective and tone. The novel offers an unusual and highly sophisticated rendition of much of the same historical material that Mqhayi had brought readers, but Mda inserts this material into a complex double narrative, set in different time-frames but similar areas (mostly, the Eastern Cape region, heartland of the Xhosa-speaking tribes). The two 
main narratives weave together (sometimes bewilderingly), firstly, an historical narrative about the lives of twin Xhosa brothers who lived mainly between the war of King Hintsa (1834) and the Xhosa cattlekilling years (from 1856) and is set in the $19^{\text {th }}$ century, and secondly, a contemporary post-apartheid narrative of two distantly related elderly men, both descended from the twins of the first narrative: two old men who have inherited, or rather embraced, the fierce enmity and contrasting positions of their twin ancestors. The rival positions adopted are in both cases called (and Mqhayi had also used these terms) those of "Belief" and "Unbelief". Be it noted, though, that "Belief" here has nothing to do with a particular religious creed such as Christianity and also that a position of "Belief", as of "Unbelief", set in post-apartheid South Africa, does not mean the same as it did in the mid-19 $9^{\text {th }}$ century of colonial times. The disputed "Belief" is in the prophecies of Nongqawuse, the young Xhosa prophetess whom Mqhayi too had described, whose prophecies one twin brother passionately embraces and remains committed to (like thousands of his fellow Xhosas)-committed even until death, so fanatic at the end that not even his little son's near-starvation disturbs him. The other twin is completely sceptical about the validity of the prophecies of Nongqawuse, but remains furiously embittered and estranged from his twin because the latter had during the cattle killing time burned down his homestead and killed his cattle as if to force him to obey the prophecies, so the unbelieving twin takes no pity on his starving brother or on the latter's equally starving family, towards the later part of their lives, when the promised rewards of believing Nongqawuse's prophecies have failed to arrive.

It would take up too much space to go into the further-immense yet worthwhile-narrative complexities of Mda's novel, but the healing irony and the humour-tinged compassion (as well as exasperation) 
with which Mda's narrator regards human follies and vanities and the portrayal of the fissiparous effect on tribal (as on any!) community of a belief that becomes ideologised, in other words the destructive results of culture that has rigidified into custom, can be noted. The bitter divisions of the past have been resuscitated within modernity; shown as causing further trouble. Much of the novel is set in the very seaside location where Nongqawuse made her prophecies; the modern-day Believer and Unbeliever live there, too. The British governor at the time of the historical narrative is Sir George Grey, who had employed Wilhelm Bleek to record the /Xam Bushman language and lore previously referred to. Mda's novel mocks the God-like vanity and unbelievable condescension with which this British governor (Grey) decided how thousands of black people with an entirely different culture ought to live their lives. Whereas the Unbeliever twin in the historical period is in most respects the more sensible, astute and balanced brother, especially in that he does not reject Nongqawuse's prophecies in order to ally himself with the relentlessly advancing colonising British, but remains true to his Xhosa culture and religion, the Unbeliever in modern times is much less admirable or dignified: he is seen to be foolishly fanatic about "progress", which, he declares, "will bring modernity to our lives, and will rid us of our redness" (105) (refer here to the title and to the cover image: traditional Xhosas dyed their blankets red-brown and coated their skins with red ochre, hence becoming known as "red" in contrast with "school" or educated members of the tribe). Effectively refuting his village rival's position, the modern-day "Believer" stands up "in his traditional finery" and raises the core ecological issue: "This son of Ximiya talks of progress. Yet he wants to destroy the bush that has been here since the days of our forefathers. What kind of progress is that?"' (105). His question is at the core of this essay's evaluation of the texts discussed. 
Mqhayi had touched on the way some Xhosa kings coexisted usefully with Khoikhoi and Bushman people, whereas other Xhosa rulers had despised the Khoi/San and hunted them down; in Mda's novel, the nineteenth century Believer marries a Khoikhoi (as quite a number of Xhosa men had indeed done, although others had frowned on it); his wife tells him about the Khoikhoi cultural hero Heitsi-Eibib and teaches him her own belief system. When their later, shared belief in the prophecies of Nongqawuse proves unfulfillable, she returns to her old way of Khoikhoi worship, which Mda as modern author evokes with great respect.

Mda brings a South African born but U.S.-trained communications expert, whose skills are unappreciated in a post-apartheid system (where some connection to the ANC government is the only way to get a job), into the seaside Xhosa village. The man is himself umXhosa, though of another clan-he is enticed to the village by a woman's beautiful singing, which he hears when about to return to the States where his qualifications are appreciated. He is the figure (one might say) of the modernist who is re-traditionalised; ${ }^{14}$ Mda mocks the vulgarity and superficiality of the power-mongers in the post-apartheid government whose greed and materialism betray all real tribal values even as they practise nepotism of a superficially tribal kind.

Colonial power abuse and ruthlessness are equally sharply satirised, however. Mda seems to set up tidy binaries, but in this profoundly playful novel this is done only to demonstrate how untenable these binaries are. No position is irreproachably sound or entirely moral and no tribe, British or Xhosa, sacrosanct per se: all need to be scrutinised in terms of the criteria of compassion and responsibility. These ethical challenges are not solemnly presented, however: Mda's teasing style subjects every single character to 'dethroning' moments. The Heart of Redness is an immensely humane 
text. If, unlike the two women authors' novels, it shows tribal women who are in most cases definitely 'unsuppressable' (to coin a term), Mda also shows instances of exploitation of women by men; depicts a husband who burns down the house just because his wife has dared to suggest he take a bath before they have sex, and he demonstrates some of the sexist qualities of tribal protocol.

Mda's humour permeates the text, ranging from gentle teasing to mockery and also to occasionally quite fiercely scathing satire, depending on what conduct or attitude he evokes; his examination in this text of the function and adaptions and variations of Xhosa tribal existence is fascinatingly various. He also includes passages of lyrical beauty evoking, in the citation with which this brief account of his text is concluded, the ancient art of Xhosa split-tone singing. The person singing is a feisty young rural girl; it is she who in the end will win the heart of the city man with her potent redness and give their son the Khoikhoi name of Heitsi, as her Khoikhoi ancestress did to her own. This is how Mda evokes her singing:

She bursts into a song and plays her umrhubhe musical instrument. She whistles and sings all at the same time. Many voices come from her mouth. Deep sounds that echo like the night. Sounds that have the heaviness of a steamy summer night. Flaming sound that crackle like a veld fire. Light sounds that float like flakes of snow of top of the Amathole Mountains. Hollow sounds like laughing mountains. Coming out all at once. As if a whole choir lives in her mouth. (175)

This description of tribal music indicates the variousness and creativity, and the cherishing of the local, that Mda's text both evokes and advocates: a passage like the above could be compared to the Khoikhoi 'Song of the Rain' in its celebration of the natural, of that which is both earthly and holy; both ancient and vital. 
The penultimate text discussed here appeared in 2009; it was written by a retired Professor of Educational Psychology with an absorbing interest in Bushman anthropology. His novel takes us back into human history, evoking the life-world of the Bushmen and also providing helpful explanatory notes based on careful research. Its title is Blood's Mist, a death-time image for the San, since his text represents the life of a Bushman group at a time of dwindling resources, when white settler-farmers and black tribes had all but crowded them out and killed them off. Included below are three passages from this text, the first from the novel section, which is the text's main body:

As the rhythm and chanting became stronger, Khoe-an rose to her feet and slowly, continuing to chant, she began to dance around the other women who maintained their clapping. One by one the men all joined her. Everyone recognised the importance of this dance: it was badly needed for all their sakes [...] the rhythm and tempo rose steadily through the night until Khoean felt the !gi begin to tighten her belly. Sweat broke out on her brow. Leaning forward, almost horizontal with the ground, she thrust her arms out behind her back. Appealing, thus, to the spirits, she summoned power from them to heal all her people. A cry broke from her as she felt the !gi beginning to boil in her body. But she controlled it: held it in. Trembling, the power glistening in the sweat of her palms, she moved first to each of the women [...] Then to each of the men she moved [...] and, snoring into herself the sickness which she could see in their hearts, she snorted it vigorously away into the night. Finally, quite spent with the effort and intensity, she collapsed onto the ground. Dilai, aware of how important, how critical this healing had been for her mother, cradled her gently in her arms until her spirit returned to her body.

Xaa-ttin, meanwhile, the !gi of the dance still vibrating in him, and feeling re-energised and cleansed after Khoe-an's healing, had set off into the faint, grey light of the emerging dawn. Taking 
/Kannu with him, he made his way down the valley to the little overhang beside the river where Dilai's seclusion had taken place. Redolent of !Khwa, he had previously been to this place to call on the rain; to appeal to !Khwa. Here, some time ago, he had painted a rain animal which his spirit, flying down the wind, had captured. (108-109)

In the first set of notes on this extract, in his second role of archaeological and ethnographic researcher, the author David Donald explains the San cosmology and the "appeal to !Khwa" in the above passage. He reminds us first how crucial water was to the Bushmen and to all the other life-forms on which they depended, adding: "Not surprisingly, therefore, water carried deep meaning and spiritual importance for the Bushmen: it interlinked their whole worldview, including their mythology: their rituals; their rock art; and the realm of the spirits themselves". !Khwa, Donald informs us, was second only to the central creator-god /Kaggen and he writes: "As the spirit of water in all its forms, !Khwa was water [...] Thus he could be a violent storm, soft rain, mist, river water or the deep standing depths of the water hole" (241).

The Bushmen that Donald evokes lived in the rocky fastnesses of the Drakensberg between the provinces of KwaZulu-Natal and the Free State provinces. Donald does acknowledge that, since there are no available verbal records for the Drakensberg Bushmen, he is transposing the cosmological beliefs of the southeastern Cape San /Xam people, as recorded by Bleek and Lloyd, to a San people of a very different region. This text is, thus, a demonstrably modernist intervention at a distant remove from its purported source, and the conduct and ascribed mythology possibly partly inappropriate. Yet the gentleness of this white scholar's reimagining of San lives is very appealing and even convincing as an imaginative tribute to Bushman culture and as something (perhaps) of an apology for his 
own ancestors' role in the extermination of the San. In a further note in another section of his text, Donald mentions a particular, wellhidden but quite small rock shelter; clearly a place he has visited and where he had carefully and respectfully, even lovingly, observed the rock art. Concerning this site, the author writes that:

Prominent in the visible rock art is a huge snake-like image which, because it has a clear fish's tail, likely represents a 'water's snake,--a common form taken on by!Khwa. The body of this snake is joined with 'lines of supernatural potency' ${ }^{15}$ to what looks like either a [...] woman's gathering bag or back apron-[...] In addition, the head of the snake appears to disappear into a fault-line in the rock face; thus possibly signifying entrance into the spirit world. To the right of this powerfully symbolic painting, is another set of highly charged images that are closely associated with !Khwa: a rain animal, with a number of shamanistic 'trance-buck' swooping around it, and two other clearly mythical or trance images. Below the 'water's snake', is a row of small, delicately painted rhebuck which, as Vinnicombe has suggested, are symbolically associated with close family relationships-a particularly female concern in any culture. (251-52)

How delicately, sensitively and respectfully the discourse of scientific modernity here meets the symbolic language of a highly expressive, but non-literate culture! The mysterious nature of the images is acknowledged and no appropriative attitudes poison this small 'semi-narrative'.

The final literary text used in this essay to address the question whether encounters between the tribal and the modern necessarily result in the destruction of the tribal, or whether a mutually accommodative compromise can be found, is admittedly the most problematic example-in that it is the text that most searchingly interrogates the claims of the tribal in the contemporary South African sphere. This last text is by a young man in his twenties, 
Thando Mgqolozana-it is set in the Western Cape and mostly in the Xhosa heartland of the Eastern Cape. Titled A Man Who Is Not a Man (2009), the novel daringly breaks the taboo on revealing what happens during the male initiation rate of the amaXhosa. They have the saying that "What happens on the mountain stays on the mountain". The word "mountain" in this proverb refers, even if some youngsters are initiated in non-mountainous areas, to the traditionally inaccessible or hidden area up or out in the wild, where male initiation takes place-away from the social scene and particularly not perceivable nor to be spied upon by women, uninitiated young men, or children. Mgqolozana has not only dared to break the taboo by revealing (in considerable detail!) "what happens on the mountain" to everyone who reads his novel, but more specifically by his raising the issue (in it) of circumcisions that go wrong-resulting in mutilation, castration, social humiliation or even death of young Xhosa men. Every year, in increasing numbers as those with adequate circumcision skills perhaps grow fewer, or perhaps as a modern human rights culture evolves in our society and more democratic questioning of formerly unchallengeable traditions occurs, scores of young amaXhosa initiates' deaths are reported. More of them are scarred for life, both physically and emotionally, by the stigma of not having been 'man enough' to endure the initiation to the end, or for having chosen to go to hospital to save their lives. Mgqolozana has daringly raised all the above matters in his novel, thus deliberately entering the "public sphere" (on this, compare Lara 1998, below).

Hearteningly, Mgqolozana has not been widely denounced as a betrayer of Xhosa tribal culture, since many (my impression is, most) reviewers (and amaXhosa among them) have hailed Mgqolozana's courage and the risky but socially and, I would add (perhaps controversially) the tribally, culturally, responsible step he took in 
writing this text. The cover image shows the unsmiling, possibly anguished face of an umkhweta, as an initiate is called during the initiation period, which involves in addition to the traditional circumcision, health and hygiene training, learning the Xhosa culture's rules of male adulthood and includes teachings concerning proper sexual conduct.

What makes Mgqolozana's narrative worthy of respect is that it is not an attack on the ritual from the perspective of self-indulgent, arrogant youth who sneer at ideals of endurance and traditionally directed male elder and adult socialisation of younger Xhosa men. Indeed, the focalising character in the story, after a period of juvenile delinquency and petty but risky crime committed while living with his neglectful and sadly alcoholic father in Cape Town, gets sent back to the rural areas to live with his grandparents and to finish school. Here, he settles down, falls in love for the first time and is in fact eager (though also, naturally, apprehensive) to undergo the ritual that will give him entry to the status of adult male in Xhosa society. (Note that the Zulu people, fellow Ngunis, do not practise circumcision, since the practice was abolished by King Shaka.) What the author does attack is not the initiation practice, itself, then, but its life-threatening and morally irresponsible, present-day deterioration.

The novel's protagonist's father is not there for him during this testing time, while his maternal grandfather, who is supposed to oversee the proper execution of the rite (he, too is an alcoholic though in a rural village setting), delegates the role of guardianship to the initiate's uncle, who in turn is suddenly called away, on the crucial morning, to take a job with a nearby white farmer-even though he was not obliged to go. Hence, the initiate has no adult attendant (as he ought to have had) and, although his cut heals perfectly, he probably binds the wound too tightly, so that his penis head becomes 
gangrenous and literally starts rotting away. I apologise for this brutal description, but this is the crucial point that the author insists we face: that vulnerable young men, through male adults' failure to maintain the custom diligently while demanding that the youths continue to undergo it, are damaging and even destroying the very manhood they claim to be forming.

Worse than the physical pain and the shame about his now deformed organ is the taunting and ostracism to which the protagonist is subjected, even in the hospital-to which he is grudgingly taken, at least in time to save his life. Nevertheless, he comes out of the ordeal eventually with a hard-earned sense of self-worth and a deeper sense of social worth; one of the few responsible and caring men in the community had told him: "Remember this, Mkhwetha: from today, you are a man in your own right"' (151).

The above paragraph may redirect the argument towards the issue of the "public sphere", the space where individual, communal and social or national identities are often asserted, negotiated or adapted. One contemporary philosopher and literary theorist who has made interesting use of Hannah Arendt's notion of the "public sphere as the human creation of plurality with a conception of narratives as the sources of a reflexive judgement capable of envisioning utopian future" (Lara 11) is the Mexican scholar Maria Pia Lara. Although the text written by Lara invoked here is directed (as its subtitle indicates) towards "feminist narratives in the public sphere" (emphasis added), its arguments are more broadly applicable to the role of fictional writing in shaping or challenging social identities. In her Moral Textures (1998), Lara widely invokes Arendt's perception of the political and social importance and power of narratives, which she summarises as follows: 
As social beings, we are caught up in a network of expectations and obligations. The values embodied in the practices of a society and its individuals are made public and legitimized in the narratives surrounding them. Thus, Arendt's view of language opens onto the past and the future, where social subjects are caught in their own signifying practices, sustained by them and produced by them. (Lara 43-44)

In the foregoing assessment of the ways South Africa's verbal artists have portrayed and engaged with the local variations of tribalism and the various local adaptations of modernity, the aim has been to show that, as Arendt indicates, writers have taken on the responsibility of making contributions to the requirement for civic identities to be adaptable in an increasingly culturally multifarious context. Particularly noteworthy is the fact that older literary texts can be most usefully and 'educationally'16 employed to indicate how the sometimes uneasy oscillations in our society between the poles of tribalism and modernity were negotiated in earlier times and by older writers, showing how long ago the issue began to manifest itself and how creatively writers and social groups of earlier times took up the challenge of weaving together these 'modern' and 'traditional' strands. Achebe has wisely said: "The consciousness of a nation is built up over centuries" and: "This is absolutely what literature does: to locate a people in the world" (Achebe 24).

To conclude, necessarily briefly: South African writers of stature portray the tribal-modernity encounter with the required and appropriate affective nuance and moral insight. Bakhtin reminds us of the "special relationship" that has always existed between the novel and "the genres of everyday life", and that the novel as text "is constructed in a zone of contact with the incomplete events of a particular present" (33). In considering texts like the seven examples used in the present essay, individually and in conjunction, a balanced 
picture emerges that leaves one with richer insight as to the wonder, worth and value of many tribal practices and cultures, while they also necessarily caution us against the typical dangers of a tribal culture deteriorating into an inappropriate, unadaptive, socially unsuitable and even individually threatening set of customs. Our society should practise the type of social ecology that Mda in his novel advocates, allowing space to the tribal as to the modern, but asking of both tribalism and modernity that they enhance the quality of social life and promote human fulfilment in all its diversity.

\section{Notes}

1 The author refers here to the various languages that feature "clicking sounds", such as the widely spoken Xhosa language. -- Editor's note

2 Khoekhoe/ Khoikhoi are variant spellings; the name reflects their pride in themselves and means "men of men" or "true people"; they were insultingly called "Hottentots" by Dutch \& British colonialists.

3 Cited in The Bushmen of Southern Africa by Andy Smith et al. (2000), 62.

4 Cited in A Bewitched Crossroad by Bessie Head, (27).

5 Adapt or Die: The End of White Politics in South Africa by Robert Schrire (Cape Town: David Philip, 1992), 220-222.

6 Other sources (e.g. the Cambridge History of Africa, Vol 7, ed. Roberts, 233) say that the earliest African-edited newspaper was Isigidimi Lama Xosa, which started in 1876, while 1884 was when J.T. Jabavu, former Isigidimi ed., started Imvo Zabantusundu, "the first newspaper in South Africa owned and controlled by Africans" (op. cit.). It was published in both English and Xhosa.

7 The English translation by Jaques Coetzee is titled The Rain Bull and other tales from the San and appeared only very recently (2007).

8 In the addendum I provide my own English translation; Coetzee's version appears in his published translation (Rain Bull 27-28). 
9 Cf. Mqhayi "what we are fighting is tradition, because it clings to usand it will succeed in harming us if we do not enter into the blood of Christ", (240).

10 "Culture has never the translucidity of custom; it abhors all simplification. In its essence it is opposed to custom, for custom is always the deterioration of culture. This desire to attach oneself to tradition or bring abandoned traditions to life ... [may mean] opposing one's own people", (180).

11 Extracts from Antjie Krog, Ncebakazi Saliwa \& Koos Oosthuizen's translation; cited from the website <http://southafrica. poetryinternationalweb.org/piw_cms/cms/cms_module/index. php?obj_id=13291\&x=1>

12 Mandela: Long Walk to Freedom, the Autobiography of Nelson Rolihlala Mandela.

13 Compare the sensitive exploration of this issue of black women's "waiting" in Njabulo Ndebele's recently published The Cry of Winnie Mandela.

14 Cf. Attwells' distinction, with reference to the Zulu poets Herbert Vilakazi \& R.R.R. Dhlomo, between "modernising tradition" and "traditionalising modernity" (Attwell 77-110).

15 Apparently citing Deacon and Forest (2005:109), Donald goes on to cite (further?) from their text (see Donald 251, footnote 190).

16 See Chinua Achebe's essay on and view of "The novelist as teacher" (Achebe 1975) and his interview, "Mapping out Identity" (Achebe 1984).

\section{References}

Achebe, Chinua. "Mapping out Identity: An interview with Chinua Achebe." The Classic 3.1(1984): 24-25.

. "The Novelist as Teacher" Morning Yet on Creation Day: Essays. (London: Heinemann, 1975): 42-45.

Attwell, David. Rewriting Modernity: Studies in black South African literary history. Scottsville: KwaZulu-Natal Press, 2005. 
Bakhtin, Mikhail M. The Dialogic Imagination: Four Essays. 1975.Ed. Michael Holquist; trans. C. Emerson and M. Holquist. Austin: University of Texas Press, 1990.

Deacon, J. and Foster, C. My heart stands in the hill. Cape Town: Struik, 2005.

Donald, David. Blood's Mist. Johannesburg: Jacana, 2009.

Fanon, Frantz. The Wretched of the Earth. Trans. C. Farrington. Harmondsworth: Penguin, 1963.

Head, Bessie. A Question of Power. Oxford: Heinemann, 1974.

. The Collector of Treasures and other Botswana village tales. London: Heinemann, 1977.

. A Bewitched Crossroad: An African Saga. Johannesburg: Ad. Donker, 1984.

Hendrik: see Marais, E. (below).

Lara, Maria Pia. Moral Textures: Feminist Narratives in the Public Sphere. Berkeley/ Los Angeles/ London: University of California Press, 1998.

Mandela, Nelson Rolihlala. Long Walk to Freedom: the autobiography of Nelson Mandela. Randburg: Macdonald Purnell, 1994.

Marais, Eugène N. The Rain Bull and other tales from the San. 1921. Cape Town: Human \& Rousseau, 2007. Trans. Jacques Coetzee of the Dwaalstories, told to Marais by Hendrik.

Mda, Zakes. The Heart of Redness. Cape Town: Oxford University Press Southern Africa, 2000.

Mgqhayi, S.E.K. Abantu Besizwe: Historical and biographical writings, 1902- 1944. Edited and translated by Jeff Opland. Johannesburg: Wits University Press, 2009.

. "Sinking of the Mendi." 1917. 2008. Trans. Antjie Krog, Ncebakazi Saliwa and Koos Oosthuizen. <http://southafrica.poetryinternationalweb. org/piw_cms/cms/cms_module/index.php?obj_id=13291\&x1>, 17 Oct. 2009.

Mgqolozana, Thando. A Man Who Is Not a Man. Scottsville: University of KwaZulu-Natal Press, 2009. 
Ndebele, Njabulo. The Cry of Winnie Mandela. Cape Town: David Philip, 2003.

Ngcobo, Lauretta. And They Didn't Die. 1990. Pietermaritzburg: University of Natal Press, 1999.

Roberts, A.D. ed. The Cambridge History of Africa, Vol. 7. Cambridge: Cambridge University Press, 1986.

Schrire, Robert. Adapt or Die: The end of white politics in South Africa. Cape Town: David Philip, 1992.

Smith, Andy et al. The Bushmen of Southern Africa: A foraging society in transition. Cape Town: David Philip and Athens, Ohio: Ohio University Press, 2000.

Wessels, Michael. Bushman Letters: Interpreting /Xam Narrative. Johannesburg: Wits University Press, 2010.

Wilson, Francis. Dinosaurs, Diamonds and Democracy: A short, short history of South Africa. Cape Town: Umuzi, 2010. 


\section{Addendum}

\section{THE SONG OF THE RAIN}

(By Bent Joggom Counterdance)

First she peeps slyly over the mountain-top,

And her eyes are shy;

And she laughs softly.

And from afar off she beckons with one hand.

Her bracelets shimmer and her necklaces shine,

She calls softly.

And she tells the winds of the dance.

And she invites them, for the yard is wide and the wedding grand.

The big game rush up from the plain.

They dam up on the hilltop.

Their nostrils stretch wide, And they swallow the wind;

And they bend down, to see her faint tracks in the sand.

The little folk under the earth hear the drag of her feet, And they creep closer and sing softly:

“Our Sister! Our Sister! You've come! You've come!”

And her necklaces shake,

Until even the eldest on the sleeping mats wake up in the night And they talk in the dark;

And her copper ring catches the last light of the sun.

On her forehead is the fiery plume of the mountain eagle;

She steps down from the heights; 
72 Annie Gagiano, Selected $20^{\text {th }}$ and $21^{\text {st }}$ century..

She spreads out the grey kaross ${ }^{\star}$ with both her arms;

The wind loses its breath.

Oh, the dance of our Sister!

* A skin cloak. Translation of the Afrikaans original in Eugène N. Marais's record of Hendrik's tales published as Dwaalstories (Kaapstad/ Pretoria: Human \& Rousseau, 2006 [1921] second edition) by Annie Gagiano (26-28).

[Received in 28/06/2011.Approved in 23/11/2011] 